Supplement of Biogeosciences, 17, 4545-4557, 2020

https://doi.org/10.5194/bg-17-4545-2020-supplement

(C) Author(s) 2020. This work is distributed under

the Creative Commons Attribution 4.0 License.

(c) (1)

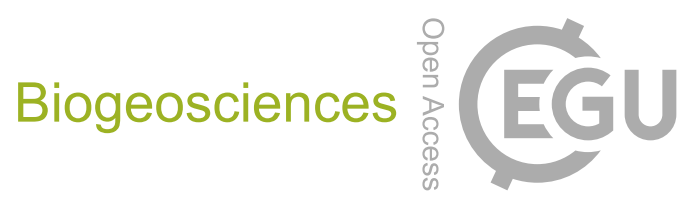

Supplement of

\title{
Modern calibration of Poa flabellata (tussac grass) as a new paleoclimate proxy in the South Atlantic
}

Dulcinea V. Groff et al.

Correspondence to: Dulcinea V. Groff (dulcineavgroff@gmail.com)

The copyright of individual parts of the supplement might differ from the CC BY 4.0 License. 


\section{Supplementary Text 1.}

\section{Temperature comparison among iButton and weather stations}

To record temperature and relative humidity, iButton ${ }^{\mathrm{TM}}$ DS1923 loggers (Maxim Integrated, Dallas, TX, USA) were placed in the Palmex samplers such that they were protected from direct contact with precipitation, but were open to ambient conditions. The temperature accuracy and resolution of iButton is $0.5^{\circ} \mathrm{C}$ and $0.0625^{\circ} \mathrm{C}$, respectively, and a resolution of $0.04 \%$ for relative humidity. Temperature and humidity were logged every two hours (12 measurements/day) and averaged to daily values for analysis. Daily average temperature $\left({ }^{\circ} \mathrm{C}\right)$ and relative humidity $(\%)$ were calculated from two-hour measurements using iButton loggers at Bleaker Island, Cape Dolphin, Surf Bay, West Point Island sites (Fig. 1b-c), and daily average temperature of 15-minute measurements using MetPak II (Gill Instruments, UK) at Bleaker Island (Fig. S1).

To determine the validity of the iButton temperature data, we compared temperature $\left({ }^{\circ} \mathrm{C}\right)$ measurements logged every two hours with an iButton at Bleaker Island with those from a local weather station taken every 15 minutes (MetPak II supplied by Gill Instruments, UK; hereafter referred to as Bleaker WSD). The elevation at Bleaker WSD is approximately $1.74 \mathrm{~m}$ above sea level, and $\sim 10 \mathrm{~m}$ higher than the iButton, which was positioned $350 \mathrm{~m}$ to the northwest. These measurements were compared to data from the Mt. Pleasant Airport weather station, located $50 \mathrm{~km}$ northeast of Bleaker, which records temperature, wind speed, and wind direction downloaded from the Global Summary of the Day (GSOD) hosted at the National Climate Data Center (Downloaded at https://www7.ncdc.noaa.gov/CDO/cdoselect.cmd). To detect differences in the median values of the seven-day running average across these three series of measurements, we analyzed the data using a Kruskal-Wallis $H$-test.

A test for normality (Shapiro-Wilk) failed $(\mathrm{P}<0.050)$, and a non-parametric KruskalWallis one-way analysis of variance on ranks indicated there are significant differences ( $\mathrm{p}$-value $<0.05)$ in the median values among the three groups $(n=365, \mathrm{H}=21.131$, $\mathrm{df}=$ $2, p<0.001)$. A Tukey test of all pairwise multiple comparisons indicated that the median running average of the Bleaker iButton $\left(5.78^{\circ} \mathrm{C}\right)$ is significantly greater $(\mathrm{p}<0.05)$ than 
Bleaker WSD $\left(5.09^{\circ} \mathrm{C}\right)$ and Mt. Pleasant GSOD $\left(5.65^{\circ} \mathrm{C}\right.$; Fig. S1). iButtons indicated that there was not a difference in temperature or humidity across all the sites; however, the Bleaker iButton indicated warmer temperatures than both the Bleaker WSD and Mt Pleasant GSOD (Fig. S1). iButton mean annual temperatures (Table 1) were similar to the mean annual temperature long term/historical MPA observations $\left({ }^{\circ} \mathrm{C}\right), 6.5^{\circ} \mathrm{C}$ and similar to MPA GSOD. The Bleaker Island iButton temperatures were correlated with Bleaker WSD and Mount Pleasant. Weekly running averages generally follow each other during the year. Cape Dolphin is the most equator-ward site, but had the lowest mean annual and mean summer temperatures. West Point Island is at a similar latitude as Cape Dolphin (Table S1), yet, had the warmest mean annual temperature of the four study sites, and the warmest mean winter and summer temperatures. West Point Island also had the largest range in \% RH and the lowest \% RH. Among the four study sites, Cape Dolphin had the highest RH in summer and winter (Table S1).

\section{Wind speed, direction, and HYSPLIT analyses}

We analyzed data from a Bleaker Island weather station (MetPak II, Gill Instruments, UK), to explore variation in sources of air masses between summer and winter, which recorded wind speed and direction at ground level from September 2015-August 2016. The frequency of counts by wind direction (\%) was measured at Bleaker Island WSD (MetPak II) across four seasons, from September 2015 to August 2016. Mean seasonal wind speed $\left(\mathrm{m} \mathrm{s}^{-1}\right)$ and $\%$ calm were calculated and a wind rose was constructed using the package openair in R (version 3.1.0). We explored variation in sources of air masses at $1000 \mathrm{~m}$ above ground level from September 2015 to August 2016, using the Hybrid Single-Particle Lagrangian Integrated Trajectory (HYSPLIT) model (NOAA Air Resources Laboratory; Draxler et al., 1999). We selected global reanalysis data sets from the National Centers for Environmental Prediction (NCEP) and the National Center for Atmospheric Research (NCAR; Kalnay et al., 1996; Kistler et al., 2001) as the NCEP/NCAR reanalysis model is suitable for the Southern Hemisphere based on previous work of back trajectory modeling to determine the origin of air masses (Gasso \& Stein, 2007; Dixon et al., 2011; Markle et al., 2012; Schwank et al., 2017) Five-day (120 h) 3-D back trajectories were created for a central point over the Falkland Islands $\left(51.79^{\circ}\right.$ 
S, $59.52^{\circ} \mathrm{W}$ ) from 1 December 2015 to 29 February 2016 (summer) and 1 June 2016 to 30 August 2016 (winter). 
Supplementary Fig. S1. Comparison of ambient temperature measurements measured by various devices from Bleaker Island and Mount Pleasant, East Falkland Island between September 1, 2015 to August 31, 2016. Daily averages were computed using 2-h measurements with the iButton (red circle symbol), hourly measurements for the Mt. Pleasant Global Summary of the Day (GSOD; black triangle symbol), and 15-minute measurements at the Bleaker Island weather station (WSD; blue square symbol). A seven-day running average (line) was calculated from the daily averages for each dataset. Tails of each running average were computed by appending in SigmaPlot (v. 12.5).

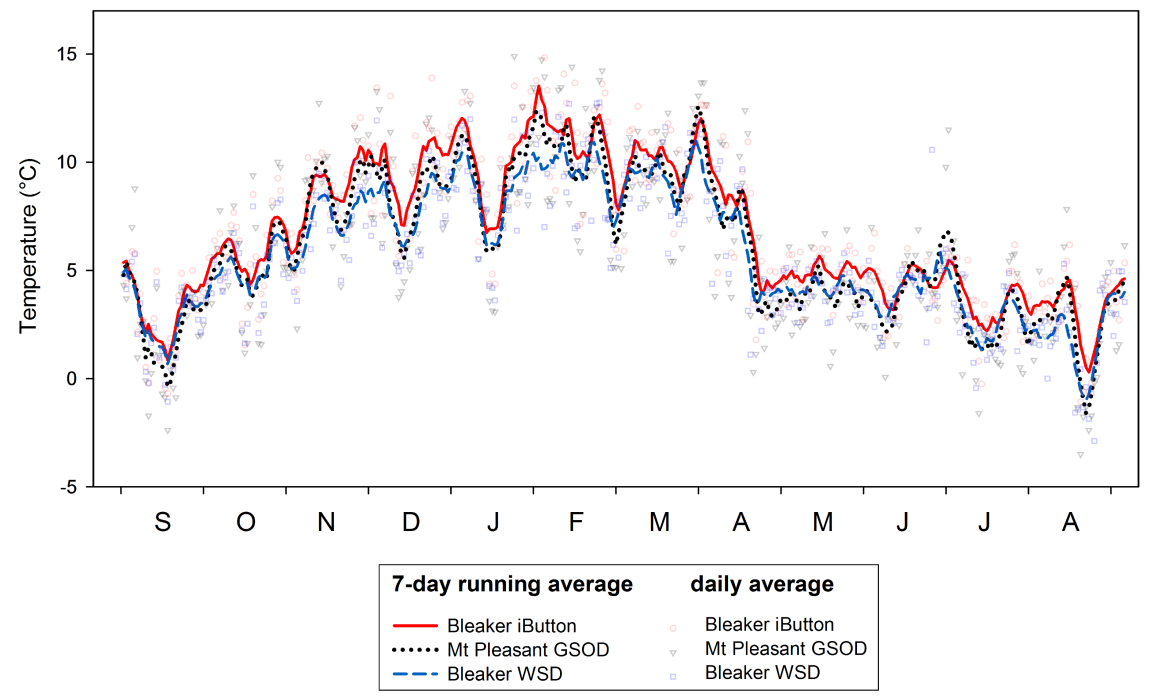


Supplementary Fig. S2. ERA-Interim reanalysis [ $3^{\text {rd }}$ generation] data showing

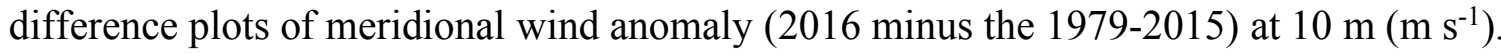
Panel a) illustrates the austral summer (DJF) and b) is the austral winter (JJA). Contour plots from Climate Reanalyzer (https://climatereanalyzer.org/), Climate Change Institute, University of Maine, USA.

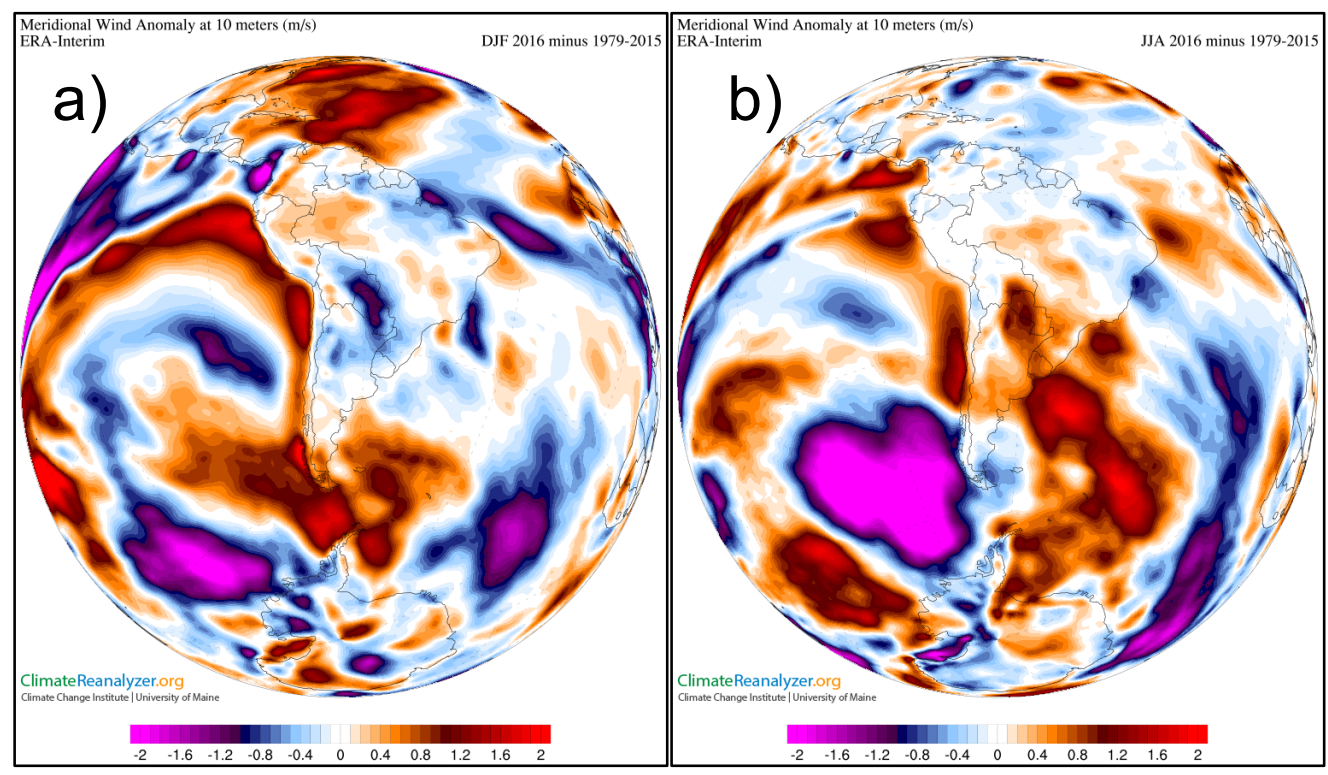


Supplementary Fig. S3. Seasonal precipitation amount from weighted monthly averages $(\mathrm{mm})$ for historical climate records in the Falkland Islands (Jones et al., 2013; Lister and Jones, 2015).

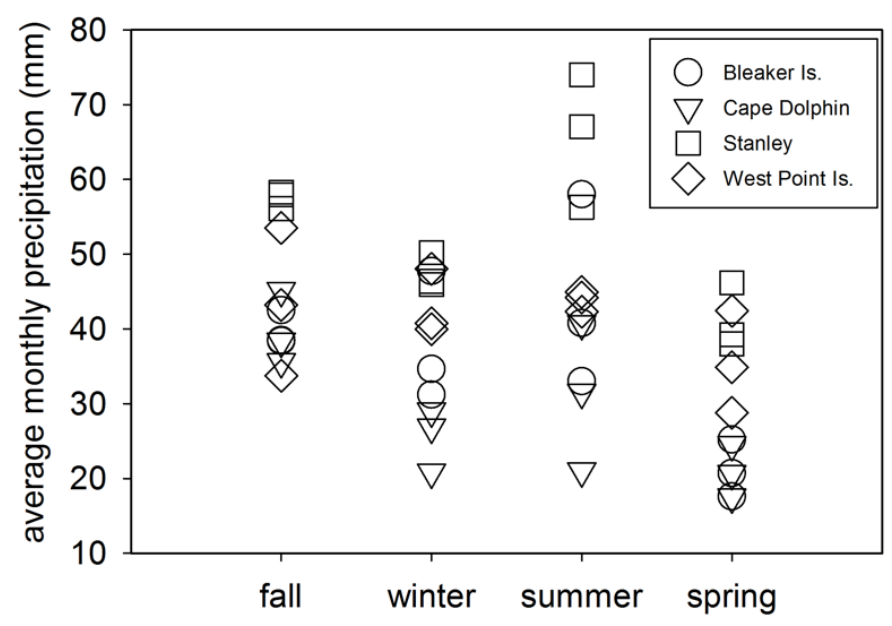


Supplementary Table S1. Summary of sites. Elevation (m) above sea level, geographic coordinates, mean annual and seasonal (summer and winter) temperature $\left({ }^{\circ} \mathrm{C}\right)$ and relative humidity $(\%)$ measured with iButton data loggers every two hours.

\begin{tabular}{|c|c|c|c|c|c|c|c|c|}
\hline \multicolumn{3}{|c|}{ Site information } & \multicolumn{3}{|c|}{$\begin{array}{l}\text { Temperature }\left({ }^{\circ} \mathrm{C}\right) \\
\text { mean (min-max) }\end{array}$} & \multicolumn{3}{|c|}{$\begin{array}{l}\text { Relative humidity (\%) } \\
\text { mean (min-max) }\end{array}$} \\
\hline Site (elevation) & Lat (S) & Long (W) & Mean annual & Mean summer & Mean winter & Mean annual & Mean summer & Mean winter \\
\hline Surf Bay (4 m) & 51.7012 & -57.7858 & 6.32 & $\begin{array}{c}9.94 \\
(4.30-15.30)\end{array}$ & $\begin{array}{c}3.30 \\
(-1.33-6.51)\end{array}$ & 87.97 & $\begin{array}{c}80.47 \\
(64.87-95.17)\end{array}$ & $\begin{array}{c}94.37 \\
(79.07-100)\end{array}$ \\
\hline West Point Is. $(30 \mathrm{~m})$ & 51.3505 & -60.6875 & 6.96 & $\begin{array}{c}10.55 \\
(5.26-15.60)\end{array}$ & $\begin{array}{c}4.54 \\
(-0.57-7.56)\end{array}$ & 86.99 & $\begin{array}{c}80.09 \\
(64.17-98.07)\end{array}$ & $\begin{array}{c}91.77 \\
(73.65-100)\end{array}$ \\
\hline Cape Dolphin (33 m) & 51.3420 & -58.8425 & 5.95 & $\begin{array}{c}9.52 \\
(3.48-13.81)\end{array}$ & $\begin{array}{c}3.20 \\
(-1.78-6.31)\end{array}$ & 90.14 & $\begin{array}{c}82.79 \\
(69.94-96.27)\end{array}$ & $\begin{array}{c}95.70 \\
(84.51-100)\end{array}$ \\
\hline Bleaker Is. (6 m) & 52.2065 & -58.8508 & 6.63 & $\begin{array}{c}10.16 \\
(4.50-14.93) \\
\end{array}$ & $\begin{array}{c}3.63 \\
(-0.92-6.31) \\
\end{array}$ & 88.46 & $\begin{array}{c}80.82 \\
(66.32-94.44)\end{array}$ & $\begin{array}{c}95.33 \\
(79.83-100) \\
\end{array}$ \\
\hline
\end{tabular}


Supplementary Table S2. Summary of mean summer and winter isotopes of $\alpha$-cellulose in leaves and roots with \pm SD. All values are per mil (\%).

\begin{tabular}{ccccccccc}
\hline$\alpha$-cellulose & Min & Max & Range & Summer & $\mathrm{n}$ & Winter & $\begin{array}{c}\text { Difference of } \\
\text { means }\end{array}$ \\
\hline$\delta^{13} \mathrm{C}_{\text {leaf }}$ & -30.41 & -21.95 & 8.47 & $-24.27 \pm 1.05$ & 39 & $-26.80 \pm 1.39$ & 36 & 2.55 \\
$\delta^{13} \mathrm{C}_{\text {root }}$ & -29.83 & -23.45 & 6.38 & $-25.35 \pm 1.27$ & 18 & $-26.67 \pm 1.38$ & 18 & 1.32 \\
$\delta^{18} \mathrm{O}_{\text {leaf }}$ & 26.38 & 31.84 & 5.45 & $30.16 \pm 0.83$ & 39 & $27.53 \pm 0.62$ & 36 & 2.63 \\
$\delta^{18} \mathrm{O}_{\text {root }}$ & 27.48 & 31.02 & 3.54 & $28.88 \pm 1.04$ & 18 & $28.39 \pm 0.59$ & 18 & 0.28 \\
\hline
\end{tabular}

